\title{
Implementation of Compensation for Oil Pollution by Tanker Ships in the Indonesian Legal System
}

\author{
Elly Kristiani Purwendah ${ }^{1, *}$ and Dewa Gede Sudika Mangku ${ }^{2}$
}

${ }^{1}$ Faculty of Law, Universitas Wijayakusuma, Jalan Raya Beji Karangsalam Purwokerto Indonesia

${ }^{2}$ Faculty of Law and Social Sciences, Universitas Pendidikan Ganesha, Jalan Udayana No. 11 Singaraja Bali Indonesia

Abstract: The government needs to restructure the institutions that are responsible for prosecution and the calculation of appropriate compensation to avoid the time-consuming and complicated process of calculating losses and need to establish a loss adjuster agency. The Coordinating Ministry for Maritime Affairs is expected to be the coordinator, coordinating other agencies based on a marine data base and a method of calculating compensation for all existing resources. It is necessary to create a special procedural law system for environmental compensation considering the application of the precautionary principle, the polluter pays principle and strict liability in cases of tanker oil pollution which have special characteristics given the civil responsibility and liability for Protection \& Indemnity (P\&I) insurance.

Keywords: Compensation, oil pollution, tankers, legal system.

\section{INTRODUCTION}

Indonesia is an archipelago country, the largest archipelago country in the world, has abundant marine wealth. The length of the coast is $81,000 \mathrm{~km}$ or $14 \%$ of the worldwide coastline, where $2 / 3$ of Indonesia's territory is marine waters (Astiti, 2020). Sovereign sea area 3.1 million $\mathrm{km} 2$ Sea area of the EEZ (Exclusive Economic Zone) 2.7 million $\mathrm{km} 2$. The sea is a land that is rich in natural resources including a variety of biological resources, all of which can be utilized for the prosperity and welfare of the community. As it is known that $70 \%$ of the earth's surface is covered by waters/oceans and more than $90 \%$ of the biomass life on planet Earth lives in the sea (UNEP, 2004).

Therefore, the ocean is an important part of human survival, you can imagine if the ocean is polluted/damaged so that some of the biomass is polluted. Meanwhile $60 \%$ of the earth's human population lives within $60 \mathrm{~km}$ of a coast which is highly dependent on marine products. Therefore, all components of the state are responsible and obliged to preserve the condition and existence of the sea according to its form, including preventing pollution. Marine pollution is defined as the presence of dirt or waste products from the activities of living things that enter the sea area (Purwendah, 2020).

The marine environment is part of a country's economy. With a coastline of approximately 95,181 km, Indonesian waters have high potential. This measure is

*Address correspondence to this author at the Universitas Wijayakusuma Purwokerto, Indonesia; Tel/Fax: +62 281643 9756;

E-mail: elly_kristiani@yahoo.co.id second only to Canada as a country that has the second-longest coastline in the world (Bohlen, 1911). The economic value of the sea is estimated at the US \$ 3 trillion - US $\$ 5$ trillion or equivalent to Rp. 36,000 trillion - Rp. 60,000 trillion per year. This figure does not include other potentials that come from the wealth of biotechnology, marine tourism and marine transportation development (Sakti, 2020).

Considering the very strategic role of the sea because some people rely on the sea for their livelihoods and livelihoods, the sea needs to receive major attention in law enforcement, especially from the impact of ecosystem damage due to pollution. Sources of marine pollution can come from: (1) pollution caused or originating from ships; (2) pollution originating from oil drilling installations; (3) sources of pollution on land; and (4) air pollution (Collin, 2008). The problem of oil pollution due to ship (tanker) accidents in Indonesia needs serious attention concerning the right to sue (ius standi), evidence related to scientific verification to explain causal relationships, application of the principle of compensation, coverage, and extent of environmental issues to determine the amount of compensation, and environmental restoration criteria related to the formal truth system adopted in the civil compensation prosecution system (D'Andrea, 2006).

Claims for compensation based on the interests of the marine environment as well as the blue economy concept proclaimed by the government must, of course, be the basis for the claims of losses given by polluters to restore victims, both human victims (fishermen) and victims of the marine ecosystem, considering that several international instruments have 
been ratified by the system (Dempsey, 1980). National law regarding provisions regulating compensation for oil pollution by tankers. Recently at Teluk Penyu Beach, Cilacap, there was a problem of prosecuting compensation for oil pollution. On Monday, 25 May 2015, there was a huge oil spill in the waters of the Cilacap sea. On Monday, 25 May 2015, residents and fishermen were busy with activities to collect the spilled crude oil that contaminated the tourist area of Teluk Penyu Beach in Cilacap Regency, Central Java. The spills came from the leakage of the pipeline for the loading and unloading facilities of Pertamina Refinery Unit IV Cilacap which was damaged on Wednesday night, May 20, 2015 (Frank, 2006).

In the period 2011-2015, there were 4 (four) oil contaminations in the Cilacap sea. In 2011 there were two cases of pollution in July and September by the Super Tanker Ship TT. Arenza XXVII and Ship MT. Medelin Atlas Belawan IMO 8717245, and in April 2012 the MV. Indo Baruna $V$ is polluting the marine environment of Cilacap. Most recently in 2015 in May 2015 tanker ship MT. Martha Petrol. Demands for compensation for oil pollution by tankers in Cilacap sea were made by fishermen to PT. Pertamina through direct claims. The calculation of compensation is calculated as the direct loss of fishermen who cannot go to sea during pollution multiplied by the number of fishermen who are registered as members of the Indonesian Fishermen's Association (HNSI). The Indonesian Fishermen Association (HNSI) Cilacap Regency asks for compensation of IDR 40.7 billion from PT Pertamina RU IV Cilacap due to oil leakage (Andri, 1999).

Claims for direct marine pollution compensation by fishermen without the participation of the state are not following the state's obligations as regulated in the constitutional basis of the 1945 Constitution, Article 33 Paragraph 3 which states that, "the earth and water and the natural resources contained therein are controlled by state and used for the greatest prosperity of the people ". Oil pollution in the Cilacap Sea leaves many problems, therefore this study seeks to examine the problem of compensation for oil spills at sea as a result of tanker accidents. The fair value of compensation for oil pollution due to tanker accidents needs to be studied in depth considering the function of the sea as a potential natural resource.

\section{RESEARCH AIM}

The purpose of this research is to analyze the relationship between the roles of institutions in implementing compensation for oil pollution due to ship accidents in the Indonesian legal system.

\section{LITERATUR REVIEW}

\subsection{Definition of Indemnity}

Compensation in the field of civil law is the provision of an equal amount of achievement as a result of an act that causes the loss to be suffered by one of the parties agreeing/consensus. The regulation of revocation of rights during the reign of the Dutch East Indies, (onteigenings ordonantie / Staatsblad 1920574) in hoofdstuk IV, used the term schadeloostelling which means almost the same as schadevergoeding (Wiratmaja, 2020). Compensation for losses (schade) and costs incurred (processkosten) experienced by the land owner. The meaning of compensation according to the general dictionary in Indonesian is money to recover people's losses (Ariany, 2011).

As for the definition of compensation by Law Number 2 of 2012 concerning Land Acquisition for Development for Public Interest Article 1 paragraph (10), namely: "Compensation is a reasonable and fair compensation to the entitled parties in the land acquisition process." The definition of loss according to R. Setiawan (1977) is a real loss that occurs because of default. The amount of loss is determined by comparing the state of wealth after default with the situation if there was no default.

Yahya Harahap (1986) also argues about the same loss, where compensation is a "real loss" or "fietelijke nadeel" incurred by an act of default. This real loss is determined by a comparison of the circumstances not made by the debtor. Further discussed by Harahap, if so we can take a formula, the amount of compensation is approximately the amount that is "reasonable" following the value of the achievement which is the object of the agreement compared to the circumstances that caused the default. Or some argue that the amount of compensation is "in the amount of real losses" suffered by the creditor which causes a deficiency in the value of the profits he will get (Force, 2011).

When we examine in-depth, loss is a relative sense, which rests on a comparison between two circumstances. Loss is the difference (which is detrimental) between circumstances arising as a result of the violation of the norm that does not occur. So that it can be drawn a statement regarding the loss is a situation of reducing the assets of one of the parties 
resulting from an engagement (either through an agreement or through law) due to violations of norms by other parties (Freestone, 1994).

\subsection{Definition of Marine Pollution}

Marine pollution is the entry or entry of living things, substances, energy, and/or other components into the marine environment by human activities so that they exceed the established quality standards of the marine environment. The marine pollution includes: a. Pollution originating from the mainland; $b$. Pollution originating from activities at sea; and c. Pollution comes from activities from the air (Geistfeld, M., 2001).

According to Mochtar Kusumaatmadja (1978), marine pollution is a change in the marine environment that occurs as a result of the direct or indirect inclusion of energy materials into the marine environment (including river estuaries) which results in such bad consequences as a loss to biological wealth. danger to human health, disturbance to activities at sea including fisheries and other fair use of the sea, deterioration of the quality of sea water and declining places of settlement and recreation (Gore, 1995).

Marine pollution has quite an impact on the surrounding environment, especially if the surrounding is a residential area where residents generally work as sailors or fishermen. Marine pollution is caused by human actions and the danger resulting from pollution of the ecological stability of the sea. Pollution will be bad for life or the marine environment depending on where it occurs. This hurts the fertility of biological productivity in an unequally divided ocean (Glotzbach, Stefanie, 2011).

Marine pollution is defined as the presence of dirt or waste products from the activities of living things that enter the sea area (Handl, G., 1983). Sources of marine pollution include oil spills, ship processing waste, industrial waste into the sea, oil drilling processes at sea and waste disposal from the community. However, the main source of marine pollution comes from oil spills, either from processes on ships, offshore drilling or from ship accidents and sea sand mining. Pollution from oil spills in the sea as well as mining of sea sand is a source of marine pollution which is always a problem among coastal communities because the consequences will be felt very quickly by the people around the coast and very significantly damage the ecosystem around the sea (Harrison, James, 2009).

\subsection{Principle of Absolute Responsibility in Environmental Pollution}

The principle of responsibility in solving the environment, especially pollution, uses the principle of absolute responsibility, namely strict liability and absolute liability. Strict liability is a direct and immediate responsibility, a conditional responsibility with a limitation on the number of compensation payments predetermined for marine pollution directly and instantaneously. Absolute liability is absolute and unconditional responsibility (in full and completely in compensation payments). The regulation of this principle in the laws and regulations of a country is often caused by evolution in the international world, especially with the development of environmental law (Habib, A.Z.M. Arman, 2014).

In 1978 the Indonesian government ratified the 1969 Civil Liability Convention and the 1971 Funds Convention in the national legal system through Presidential Decree Number 18 of 1978 concerning Ratification of the 1969 CLC and Presidential Decree Number 19 of 1978 concerning Ratification of the Convention for the Prevention of Pollution from ships 1973 along with the Protocol of 1978 Relating to the International Convention for the Prevention of Pollution from the Ship 1973. With the ratification of the 1969 CLC, the principle of strict liability became known in the Indonesian legal system, especially in the scope of environmental law. This concept is understood as a type of activity that can be classified as extra hazardous or hazardous or abnormally dangerous, obliged to bear all the losses incurred even though the person concerned has acted very carefully (utmost care) to prevent all dangers and losses, even though the losses arise. without any intention (Henry R.).

In strict liability, there is an obligation of the defendant to assume responsibility for losses that are not related to his fault. The defendant's obligation to assume responsibility for this loss arises immediately and immediately, once there is the fact that an event has occurred that caused the loss to occur (Himawan, Ch., 1991).

From the awareness in the community that for every action that is done either by individuals or groups, the person or group will not be able to escape responsibility for any losses caused by the act. This principle is always associated with compensation (Jing, Liu, 2013). 
The concept of hazardous, tort law imposes strict liability on activities that involve a high degree of danger that cannot be prevented by those who have acted prudently or who may be victims (Simon, 2014). The principle of strict liability has encouraged parties carrying out activities classified as extra hazardous to make several alternatives that can reduce the degree of danger. Injurers will take preventive measures at an optimal level because if they take preventive measures below the optimal level, there will be a total accident cost that must be borne (Cornelius, 1971).

\section{RESEARCH METHODS}

This research is an empirical normative legal research (applied law research). The main point of the study is the implementation or implementation of positive legal provisions in any particular legal event that occurs in society to achieve predetermined goals. Empirical normative legal research begins with written positive legal provisions that are applied to in-concrete legal events in society so that in research there is always a combination of two stages of study, namely: The first stage is a study of applicable normative law, in this case in the form of basic principles and theories regarding compensation for oil pollution due to tanker accidents; The second stage is the application of inconcreto events to achieve predetermined goals. This application can be realized through empirical research on legal cases and documents. The results of the application will create an understanding of the realization of the implementation of normative legal provisions whether it has been carried out properly or not.

Because this type of research is empirical normative legal research, the data required is secondary data and primary data. This study aims to be change-oriented (reform-oriented research), which is research that intensively evaluates the fulfillment of existing regulations and recommends changes to any regulations that are needed. This legal research is an explanatory legal study, which aims to test the suitability of the application of theory and practice for oil pollution compensation due to tanker accidents. Explanatory truth expression (explanatory or explanatory) is an expression of the truth of a study which aims to explain the data found in research activities.

To answer the problems under study, data is needed in the form of information related to the variables in question in the problem of a study. The data in this study are interpreted as questionable variable information in the research problem. In this study, the used were primary, secondary and tertiary data sources. Secondary, data in the form of positive principles and laws regarding compensation for oil pollution by tanker ships are needed as the main data in this study which is used to test the application of compensation for oil pollution due to tanker accidents in Indonesia and its institutionalization in the national legal system. Secondary data in terms of binding strength are classified into primary legal materials, secondary legal materials and tertiary legal materials.

The method/technique of collecting data to collect primary data in this study is by interview. The data collection tool used was in the form of an interview guide that was prepared based on the researcher's understanding of the object of research. Secondary data is obtained through a document study or literature study. According to Sugeng Istanto (1997), what is meant by library research is data retrieval by tracing reading materials, examining the problem variables for which the answer is sought.

Document studies are carried out on statutory regulations, documents and court decisions as well as legal materials relating to compensation for oil pollution by tankers. Methods/techniques of secondary data collection are carried out by the method of documentation, tracking literature and legal materials while the techniques used to collect primary data are using in-depth interviews, recording and, documentation.

\section{DISCUSSION}

\subsection{Implementation of Compensation for Oil Pollution by Tanker Ships in the Indonesian Legal System}

National economic development as mandated by the 1945 Constitution of the Republic of Indonesia (UUD'45) is carried out based on the principles of sustainable and environmentally sound development (Trigunawan, 2006). Also, the decreasing quality of the environment has threatened the survival of human life and other living things, so it is necessary to protect and manage the environment seriously and consistently by all stakeholders (Kim, 2000). 367 In particular, the mandate of the UUD'45 is spelled out in the section considering Law Number 32 of 2009 concerning Protection of Environmental Management (UUPPLH) which states that a good and healthy environment is 
the basic right of every Indonesian citizen as mandated in Article $28 \mathrm{H}$ of the Law. The 1945 Constitution of the Republic of Indonesia. This law states that the protection and management of the environment is a systematic and integrated effort carried out to preserve environmental functions and prevent environmental pollution and / or damage which includes planning, utilization, control. , maintenance, supervision and law enforcement (Krishna, 2010).

Natural resources in the UUPPLH are stated as elements of the environment which consist of biological and non-living resources which as a whole form an integrated ecosystem. Environmental Pollution itself is referred to as the entry or inclusion of living things, substances, energy and/or other components into the environment by human activities so as to exceed the stipulated environmental quality standards. Environmental damage is a direct and/or indirect action against the physical, chemical and/or biological characteristics of the environment that exceeds the standard criteria for environmental damage. Environmental protection and management in Indonesia as stated in Article 2 UUPPLH is implemented based on the principle; state responsibility, sustainability and sustainability, harmony and balance, cohesiveness, benefits, prudence, justice, ecoregion, biodiversity, polluter pays, participatory, local wisdom, good governance and regional autonomy (Mochtar, 1992).

Environmental protection and management include; planning, utilization, control, maintenance, supervision and law enforcement. Environmental control in this case is intended to cover prevention, mitigation and recovery carried out by the government, regional government and those in charge of businesses and / or activities their respective authorities, roles and responsibilities (Gayatri R., 1999). One of the instruments for preventing pollution and/or environmental damage consists of; environmental economic instruments, environmental-based laws and regulations, environmental-based budgets and other instruments according to the needs and/or developments of science (Librando, Gaetano, 1996).

Law Number 32 of 2014 concerning Marine states that the protection of the marine environment is a systematic and integrated effort carried out to conserve marine resources and prevent pollution and/or environmental damage in the sea which includes marine conservation, marine pollution control, marine disaster management, prevention and control of pollution, as well as damage and disasters. Marine administration is carried out based on the principles, sustainability, consistency, integration, legal certainty, partnership, equity, community participation, openness, decentralization, accountability and justice (William L, 2011).

The purpose of marine administration is to utilize marine resources sustainably for the greatest possible welfare of the present generation without sacrificing the interests of future generations (Richard A., 1992), promote marine culture and knowledge for the community, develop human resources in the marine sector who are professional, ethical, dedicated and capable of prioritizing interests. nationwide in supporting marine development in an optimal and integrated manner, and providing legal certainty and benefits for all people as an archipelagic country (Oswald, Lynda, 1993). Several articles of the Maritime Law provide an understanding of how the state's commitment to its oceans, that the state is fully responsible for protecting its marine environment with the concept of being sustainable and fulfilling justice for present generations and future generations. In this Maritime Law, the protection of the marine environment is the responsibility of the government by controlling marine pollution and preventing and overcoming pollution damage and disasters (Binawan, 2012).

Protection and preservation of the marine environment are carried out based on the provisions of laws and regulations and international maritime law. For marine governance and institutions, Article 69 explains that the government determines marine governance and institutional policies. Marine governance and institutional policies include plans for the development of a legal and governance system as well as an effective and efficient system for planning, coordination, monitoring and evaluation of marine development. In formulating marine governance and institutional policies, the government arranges maritime law in a national legal system through both public and civil aspects by taking into account international law. The interesting thing in the Maritime Law is that there is a chapter that regulates community participation, namely Chapter $\mathrm{XI}$, Article 70 which states that, the implementation of marine development is carried out by the government and local governments by involving community participation, community participation can be carried out by individuals, groups, professional organizations, business entities or other social organizations following the principles of openness and partnership (Marsudi, 1999). 
Community participation in marine development is carried out through participation in; formulating marine development policies, marine management, marine development, and providing input in evaluation and monitoring activities. Community participation can be carried out through participation in preserving cultural values and maritime perspectives and revitalizing customary law, and local wisdom in the marine sector, or protecting and disseminating underwater cultural heritage through preservation, restoration and conservation efforts (Mangku, 2020).

Law Number 17 of 2008 concerning Shipping, it aims to facilitate the national transportation system in supporting economic growth, regional development, and strengthening the country's sovereignty. In this Law, it is stated regarding the marine worthiness of ships as a condition of the ship that meets the requirements of ship safety, prevention of water pollution from ships, manning, loading lines, loading, crew welfare and passenger health, the legal status of ships, safety management and prevention of pollution from ships and security management of ships to sail in certain waters (Awaliyah, 2020).

This law also provides an understanding of the protection of the maritime environment as every effort to prevent and overcome pollution of the aquatic environment originating from activities related to shipping. The principles and objectives of this law are stated based on; principles of benefit, joint effort and kinship, healthy, fair, and equitable competition without discrimination, balance, harmony, and harmony, public interest, integrity, upholding the law, independence, environmental insight, state sovereignty and nationality. The safety and security of shipping in this law is said to cover the safety and security of transportation in waters, ports and protection of the maritime environment and is implemented by the government.

The administration of maritime environmental protection in this law is stated to be carried out by the government. The implementation of maritime environmental protection is carried out through; prevention and control of pollution from ship operations and prevention of pollution from port activities. Prevention and control of pollution from the operation of ships is regulated in this law, Article 227 states that, every ship is obliged to prevent and overcome environmental pollution originating from ships. Ships with certain types and sizes that are operated must be equipped with equipment and materials for handling oil pollution from vessels that have been approved by the government. Ships with certain types and sizes that are operated must be equipped with a pattern for handling oil pollution from ships that have been approved by the government. For the size of the ship, the obligation to deal with pollution is further regulated in the Regulation of the Minister of Transportation of the Republic of Indonesia Number PM. 45 of 2012 concerning Ship Safety Management, namely for oil tankers, chemical tankers and gas carriers with a gross tonnage size greater than or equal to GT 150 (one hundred and fifty Gross Tonnage).

After analyzing the roles and functions of each institution that plays a role in overcoming oil pollution due to tanker accidents in the Indonesian legal system, the authors divide the roles of each institution into two time periods. The first period, before 2015, before the establishment of the Ministry of Maritime Affairs. The second period after 2015, after the formation of the Coordinating Ministry for Maritime Affairs.

As a result of the analysis of the role of institutions related to the prevention and mitigation of pollution and claims for compensation for pollution, so far there have been weaknesses in the legal structure. There are conflicts of authority and interests between institutions related to the causes of compensation for pollution that cannot be given optimally.

For the period before 2015 the center for handling prevention and control is the Ministry of Transportation. The Ministry of Transportation, in this case, Dirjend Hubla, has to implement the precautionary principle through its authority in sea transportation, in this case, a tanker by ensuring that the ship administratively meets the criteria for seaworthiness to sail. One of the administrative obligations that must be fulfilled by tankers is a certificate of insurance. This insurance certificate is intended to guarantee the ship to pay compensation due to oil pollution in the process of preventing, overcoming pollution and paying for losses and restoring natural resources. The insurance certificate requirement is an application of the polluter pays principle and direct and immediate responsibility (strict liability).

For the period before 2015 the Ministry of Transportation, has a central role in preventing and overcoming oil pollution at sea due to tanker accidents, this is because the Ministry of Transportation must implement the two principles mentioned above (the polluter pays principle and strict liability). The Ministry of Transportation has the role of Chairman of the 
Pollution Prevention and Prevention Team. The Ministry of Transportation, in carrying out its duties as Team leader, is assisted by the Ministry of Environment and Forestry (KLHK) as deputy chairman. The Ministry of Environment and Forestry as deputy chairman has the authority over marine natural resources, and can file claims for compensation and restoration based on the polluter pays principle and strict liability based on civil liability for polluters through liability for marine insurance P\&I, as a legal obligation based on the ratification of the Convention on Civil Liability (CLC). However, the Ministry of Environment and Forestry has limited performance about authority relating to fish, mangroves, coral reefs and seagrass beds, because this authority rests with the authority of the Ministry of Marine Affairs and Fisheries (KKP).

The Ministry of Transportation has a limited role in preventing and overcoming pollution. The authority for environmental damage and pollution is the authority of the Ministry of Environment and Forestry. In practice this creates difficulties, considering that demands for compensation require the support of all institutions with a quick response. Partial authority becomes an obstacle in the process of prosecution and calculation of compensation because it slows down the calculation and access to evidence of pollution. Therefore the period before 2015 demands for compensation for oil pollution due to tanker accidents does not guarantee the expected value of justice. Kemenhub as team leader (Presidential Decree No. 109/2006 concerning Handling of Oil Spills in the Sea), has no interest in marine resources. This is as evident from the results of the analysis of three cases in Cilacap. Two ships with foreign flags meet the seaworthiness standard of ships including having an insurance certificate, so that when there is a compensation claim, compensation is provided through P\&I insurance, although with a limited value. Losses are calculated only up to real losses not to environmental restoration. On the other hand, compensation for ships with Indonesian flags cannot be provided because the Indonesian flagged vessels do not have a $P \& I$ insurance certificate, resulting in compensation not being provided.

With the maritime axis policy launched by the government (through Presidential Decree No. 16 of 2017 concerning Marine Policy), and the formation of the Coordinating Ministry for Maritime Affairs. In the periodization of countermeasures and prevention as well as demands for compensation for oil pollution due to tanker accidents after 2015, the Coordinating Ministry for Maritime Affairs is expected to become the
Team coordinator assisted by the KLHK. In the future, the Coordinating Ministry for Maritime Affairs is expected to have access to a loss calculation agency for marine natural resources to facilitate calculating losses in the event of pollution. This institution is like a loss adjuster whose task is to carry out an examination and/or assessment of a claim for compensation submitted by the insured (state / maritime ministry to the insurer (P\&I).

\section{CONCLUSION}

The role of the institution is differentiated into two periodisations, the first period is before 2015. The Head of the Management Team is the Ministry of Transportation (Kemenhub) and the representative is the Ministry of Environment and Forestry (KLHK). In terms of performance, between roles there are limitations of authority that make it difficult to claim compensation for compensation, the Ministry of Transportation has the authority in sea transportation and the KLHK has the authority in the environment. Coordination between roles is difficult in the era of periodization before 2015 , so inter-role improvements are needed. The second period after 2015 saw a change in the role of the ministry. The Coordinating Ministry for Maritime Affairs as the coordinator of the pollution prevention and control team assisted by the Ministry of Environment and Forestry as the deputy coordinator. The Ministry of Maritime Affairs is expected to synergize between roles so that the implementation of the precautionary principle, and the polluter pays principle can administratively be applied by the Ministry of Transportation with insurance obligations so that KLHK in filing compensation claims will have no difficulty applying the polluter pays principle and direct responsibility as the basis for compensation claims loss.

\section{SUGGESTION}

The government needs to restructure the institutions responsible for prosecution and calculation of appropriate compensation to avoid the time-consuming and complicated process of calculating losses and a loss adjuster agency is needed. The Coordinating Ministry for Maritime Affairs is expected to be the coordinator, which coordinates other agencies based on marine data bases and methods of calculating compensation for all available resources, and it is necessary to create a special procedural law system for environmental compensation considering the application of the precautionary principle, polluter 
principle and strict liability. in the case of tanker oil pollution which has special characteristics given the civil liability and liability of insurance P\&I.

\section{ACKNOWLEDGEMENTS}

We would like to thank the Chancellor of Wijayakusuma Purwokerto University, Ganesha Singaraja University of Education Chancellor, the Dean of the Faculty of Law, Wijayakusuma Purwokerto University and the Dean of the Faculty of Law and Social Sciences, Ganesha Singaraja University of Education, who have been given the widest possible opportunity to the author to research to carry out the tri dharma.

\section{REFERENCES}

Abdulkadir muhammad, 2004, Hukum dan Penelitian Hukum, Cetakan 1, PT Citra Aditya Bakti, Bandung.

Andri G. W., M. Ramdan, 1999, Masalah Ganti Kerugian Dalam Penegakan Hukum Lingkungan Secara Perdata: "Beberapa Analisis Atas Teori Pertanggungjawaban (Liability theories) Asuransi dan Dana Ganti Kerugian", Jurnal Hukum Lingkungan, Tahun $\mathrm{V}$ No 1.

Ariany, Zulfaidah, 2011, Kajian Aspek Hukum Internasional pada Kasus Tumpahan Minyak Kapal Tanker Exxon Valdez, Volume 32, Nomor 1, Tahun 2011

Astiti, M., Mangku, D. G. S.,(2020). Penyelesaian Sengketa Internasional Terkait Pencemaran Laut Timor Akibat Tumpahan Minyak Montara Antara Indonesia dan Australia. Jurnal Komunitas Yustisia, 2(1), 11-21.

Bohlen, Francis H., 1911, The Rule in Rylands v. Fletcher II, University of Pennsylvania Law Review, Vol. 59:6. https://doi.org/10.2307/3307610

Collin, Robert. W., 2008, Environmental Justice in Oregon: It's The Law: Environmental Law, Vol. 38

Compensation for Oil Pollution Due to Tanker Accidents in the Indonesian Legal System in a Justice Value Perspective

D'Andrea, Ariella, November 2006, The "Genuine Link" Concept in Responsible Fisheries (Legal Aspects and Recent Developments), Food and Agriculture Organization, Rome : Food and Agriculture Organization. Diunduh pada 30-082015, FAO Legal Papers Online 61.

Dempsey, P.S., L.L. Helling, 1 September 1980, Oil pollution by ocean vessels - an environmental tragedy: the legal regime of flags of convenience, multilateral conventions, and coastal states, Denver Journal of International Law Policy 10 (1).

Force, Robert, Martin Davies, dan Joshua S. Force, 2011, Deepwater Horizon:Removal Costs, Civil Damages, Crimes, Civil Penalties and State Remedies in Oil Spill Cases, Tulane Law Review, Vol. 85.

Frank, Veronica, 2006, Dissertation : The European Community and Marine Environmental Protection in the International Law of the Sea : Implementing Global Obligations at the Regional Level. Utrecht Universiteit. https://doi.org/10.1163/ej.9789004156951.i-482

Freestone, David, 1994, The Road from Rio: International Environmental Law after the Earth Summit, Journal of Environmental Law 6. https://doi.org/10.1093/jel/6.2.193

Geistfeld, M., 2001, Implementing the Precautionary Principle, Environmental Law Reporter, Vol. 31. https://doi.org/10.2139/ssrn.289146
Glotzbach, Stefanie, 2011, "On the Nation of Ecological Justice" dalam Working Paper Series in Economics, University of Lüneburg, Nomor 204, Mei 2011.

Gore, Albert, 1995, Marine Degradation from Land Based Activities: A Global Concern, Artikel dalam U.S. Department of States Dispatch, Vol. 6: No. 46.

Habib, A.Z.M. Arman, 2014, IOSR-JESTFT e-ISSN 2319-2402, pISSN:2319- 2399, Volume 8, Issue 9 Ver. IV (Septembre 2014) pp. 11-21.: Prevention of Oil Pollution of The Marine Environment by Ocean Vessels Compliance and Enforcement of International Law. https://doi.org/10.9790/2402-08941121

Hanafi, 2001, Analisis Ekonomi Terhadap Hukum Sebagai Upaya Peningkatan Peran Hukum dalam Pembangunan, Jurnal Hukum, No. 18 Vol.8, Oktober 2001 https://doi.org/10.20885/iustum.vol8.iss18.art13

Handl, G., 1983, International Liability of States for Marine Pollution, 21 CAN. Y.B. INT'L. L. 85 https://doi.org/10.1017/S0069005800002435

Harrison, James (Edinburgh School of Law), 2009, Regime pluralism and the global regulation of oil pollution liability and compensation, International Journal of Law in Context, Cambridge University. https://doi.org/10.1017/S174455230999022X

Henry S. Richardson, John Rawls, Internet Encyclopedia of Philosophy, http://www.iep.utm.edu/rawls/\#SH2d.

Himawan, Ch., 1991, Pendekatan Ekonomi terhadap Hukum sebagai Sarana Pengembalian Wibawa Hukum, Hukum dan Pembangunan, No. 5 Tahun XXI, Oktober 1991. https://doi.org/10.21143/jhp.vol21.no5.987

J. Peck, Cornelius, 1971, Negligence and Liability without Fault in Tort Law, Washington Law Review, Vol.46:2.

Jayawardana, Trigunawan, 2006, Tesis : Penilaian Terpadu Dampak Tumpahan Minyak di Perairan Balikpapan Studi Kasus Tumpahan Sludge Oil dari Kapal MT. Parros G. S2 UI.

Jing, Liu, 2013, Compensating Ecological Damage Comparative and Economic Observations, Disertasi, Maastrict University.

Jud, Simon, 2014, New Zealand Journal of Public and International Law, Volume 12, Number 2, December 2014, Victoria, University of Wellington, pp. 261-290: Compensation for Pollution from The Rena.

Kim, Inho, 2000, Dissertation : Restructuring the Liability Regime in the Oil Pollution Act of 1990, Doctor of The Science of Law, Stanford University.

Krishna Kiran, R. Bhanu, October-Desember 2010, Liability and Compensation for Oil Pollution Damage: An Examination of IMO Conventions.

Kusuma Atmadja, Mochtar, 1992, Perlindungan dan Pelestarian Lingkungan Laut Dilihat dari Sudut Hukum Internasional, Regional dan Nasional, Sinar Grafika dan Pusat Studi Wawasan Nusantara, Jakarta.

Librando, Gaetano, 7 Oktober 1996, Maritime Liability and Chemical Transport; International Maritime Organization Committe, Society of Chemical Industry (UK), Chemistry and Industry No. 19.

Lilley, Gayatri R., 1999, Demokrasi Pengelolaan Sumber Daya Alam, Prosiding Lokakarya Reformasi Hukum di bidang Pengelolaan Sumber Daya Alam, Cetakan I, ICEL, Pustaka Pelajar Offset.

M. yahya Harahap, 1986, Segi-Segi Hukum Perjanjian, Alumni, Bandung.

Mangku, D.G.S., Purwendah, E.K., Itasari, E.R., Nurhayati, B.R., (2020), Compensation for Oil Pollution Due to Tanker Accidents in the Indonesian Legal System in a Justice Value Perspective, International Journal of Criminology and Sociology, 2020, 9, pp. 662-669. https://doi.org/10.6000/1929-4409.2020.09.63 
Medford, William L., dan Mughda Kelkar, 2011, CERCLA vs. Code:Reconciling Conflicting Goals, American Bankruptcy Institute Journal, Vol. 30.

Mochtar Kusumaatmadja, 1978, Bunga Rampai Hukum Laut, Bandung, Bina Cipta.

N.H.T. Siahaan, 2004, Hukum Lingkungan dan Ekologi Pembangunan, Erlangga, Jakarta.

Oswald, Lynda, 1993, Strict Liability of Individuals under CERCLA: A Normative Analysisi, Environment Affairs, Vol. 20.

Postner, Richard A., 1992, Economic Analysis of Law, Fourth Edition, Little Brown and Company, Boston Toronto, London.

Purwendah, E. K. (2020). Pengaruh Bendera Kapal Bagi Kasus Pencemaran Minyak Kapal Tanker. Ganesha Civic Education Journal, 2(1), 52-65. https://doi.org/10.23887/gancej.v2i1.110

R. Setiawan, 1977, Pokok-Pokok Hukum Perikatan, Binacipta, Bandung.

Richard A. Posner, 1986, Economic Analysis of law, Little Brown \& Company, Canada.

Sakti, L. S., Mangku, D. G. S., \& Yuliartini, N. P. R. (2020). Tanggung Jawab Negara Terhadap Pencemaran Lingkungan Laut
Akibat Tumpahan Minyak Di Laut Perbatasan Indonesia Dengan Singapura Menurut Hukum Laut Internasional. Jurnal Komunitas Yustisia, 2(3), 131-140.

Siti Awaliyah, Dewa Gede Sudika Mangku, Ni Putu Rai Yuliartini, I Nengah Suastika and Ruslan, (2020), Enforcement of Illegal Fishing Laws that was Done by Foreign Ships in the Indonesian Sea Region, Viewed from International Sea Law, International Journal of Criminology and Sociology, pp. 11641173.

https://doi.org/10.6000/1929-4409.2020.09.137

Tanius Sebastian, Al Andang Binawan, 2012, Menim(b)ang Keadilan Eko-Sosial, Kertas Kerja Epistema No. 07/2012, Epistema Institute.

Triatmodjo, Marsudi, 1999, Pertanggungjawaban Negara Terhadap Pencemaran Lingkungan, Mimbar Hukum, X (33).

Wiratmaja, I. G. N. A., Mangku, D. G. S., \& Yuliartini, N. P. R. (2020). Penyelesaian Sengketa Maritime Boundary Delimitation Di Laut Karibia Dan Samudera Pasifik Antara Costa Rica Dan Nicaragua Melalui Mahkamah Internasional. Jurnal Komunitas Yustisia, 2(1), 1-10.

DOI: https://doi.org/10.6000/1929-4409.2021.10.15

(C) 2021 Purwendah and Mangku; Licensee Lifescience Global.

This is an open access article licensed under the terms of the Creative Commons Attribution Non-Commercial License (http://creativecommons.org/licenses/by-nc/3.0/) which permits unrestricted, non-commercial use, distribution and reproduction in any medium, provided the work is properly cited. 